\title{
Keikutsertaan Organisasi Keagamaan dan Empati dengan Perilaku Prososial Remaja yang Aktif dalam Organisasi Keagamaan
}

\author{
Eko A.Ariyanto1, Fitriyana Dia Ayu Ningrum ${ }^{2}$, Sahat Saragih ${ }^{3}$ \\ 1,2,3Fakultas Psikologi, Universitas 17 Agustus 1945 Surabaya \\ Email: ${ }^{1}$ eko ariyanto@untag-sby.ac.id
}

\section{Article History: \\ Received \\ 8 April 2021 \\ Review \\ 19 April 2021 \\ Revised \\ 18 Juni 2021 \\ Accepted \\ 18 Juni 2021 \\ Published \\ 23 Juni 2021}

Reviewer A:

Mulawarman
Abstract. Prosocial behavior is human behavior that is beneficial to others and can also be called behavior that helps to help, care among people without expecting anything in return. This study aims to find out: 1) the relationship between participation in organizations with prosocial behavior, 2) the relationship between empathy and prosocial behavior, 3) the relationship between the relationship between participation in religious organizations and empathy with Prosocial Behavior. The variables in this study consisted of participation in religious organizations (X1), empathy (X2), and prosocial behavior (Y). The method used in this research is quantitative method. Participants in this study were 109 adolescents who were active in religious organizations. The data of this study was obtained by distributing questionnaires to subjects who fulfilled the characteristics of the participants. The analysis technique uses the Kendall's Test with the help of Statistical Package for the Social Science (SPSS) version 20.0 for windows. The results of this study indicate that 1) there is a positive relationship between participation in religious organizations with prosocial behavior, where $41 \%$ with a significance value of $p=$ $0,000>0.05 .2)$ there is a positive relationship between empathy and prosocial behavior, where $22.5 \%$ with a significance value of $p$ $=0,000<0.05 .3)$ there is a positive relationship between a positive relationship between participation in religious organizations and empathy with Prosocial Behavior, where $14.5 \%$ with a significance value of $p=0,000<0.05$.

Keywords: Participation in Religious Organizations, Empathy, Prosocial Behavior

Abstrak. Perilaku prososial adalah perilaku manusia yang menguntungkan bagi orang lain dan dapat disebut juga menjadi perilaku tolong menolong, peduli antar manusia tanpa mengharapkan imbalan. Penelitian ini bertujaun untuk mengetahui: 1) hubungan antara keikutsertaan pada organisasi dengan perilaku prososial, 2) hubungan antara empati dengan perilaku prososial, 3) hubungan antara hubungan antara keikutsertaan pada organisasi keagamaan dan empati dengan Perilaku Prososial. Variabel dalam penelitian ini terdiri dari keikutsertaan pada organisasi keagamaan (X1), empati (X2), dan 
perilaku prososial $(\mathrm{Y})$. Metode yang digunakan dalam penelitian ini adalah metode kuantitatif. Partisipan dalam penelitian ini adalah 109 remaja yang aktif dalam organisasi keagamaan. Data penelitian ini adalah diperoleh dengan penyebaran kuesioner kepada subyek yang memenuhi karakteristik partisipan. Teknik analisis menggunakan Uji Kendall's $w$ test dengan bantuan Statistical Package for the Social Science (SPSS) versi 20.0 for windows. Hasil penelitian ini menunjukkan bahwa 1) terdapat hubungan positif antara keikutsertaan pada organisasi keagamaan dengan perilaku prososial, dimana $41 \%$ dengan nilai signifikansi $p=0,000>0,05.2$ ) terdapat hubungan positif antara empati dengan perilaku prososial, dimana $22,5 \%$ dengan nilai signifikansi $\mathrm{p}=0,000<0,05.3$ ) terdapat hubungan positif antara hubungan positif antara keikutsertaan pada organisasi keagamaan dan empati dengan Perilaku Prososial, dimana 14,5\% dengan nilai signifikansi $\mathrm{p}=0,000<0,05$.

Kata kunci: Keikutsertaan Pada Organisasi Keagamaan, Empati, Perilaku Prososial

\section{Pendahuluan}

Remaja yang tergabung dalam organisasi keagamaan cenderung tidak menunjukkan perilaku prososial dan kurang memiliki kontribusi aktif untuk membantu mengsukseskan kegiatan-kegiatan yang ada dalam organisasi keagamaan, mereka cenderung lebih pasif dibandingkan dengan individu lain yang lebih senior. Dari pengamatan yang telah saya lakukan terdapat remaja yang aktif pada organisasi keagamaan di Desa Segunung Mojokerto, dalam acara kegiatan organisasi keagamaan. terlihat ada beberapa remaja tidak mau membantu membersihkan tempat yang sudah mengadakan kegiatan rutin itu dan lebih mementingkan keasyikan diri sendiri serta tidak peduli dengan apa yang seharusnya ia lakukan, begitu juga dengan acara kerja bakti di masjid, jarang remaja yang ikut serta bergotong royong untuk membantu kegiatan itu. Sedangakan hasil penelitian yang dilakukan oleh pratitis (2013), perbedaan prososial antara siswa di kota dengan di desa menunjukkan bahwa tidak signifikan dikarenakan hasil dari perbedaan hanya selisih tidak jauh beda antara siswa yang ada di kota maupun di desa. Hasil penelitian lain yang dilakukan oleh Ting Lu dkk (2017), mengatakan bahwa perilaku prososial pada remaja perempuan yang berada di Cina lebih cenderung bertujuan untuk mempopulerkan dirinya atau agar remaja itu dikenal dengan cara menolong orang lain, seharusnya remaja mampu menolong sesama individu tanpa mengharapkan imbalan apapun.

Penurunan kecenderungan remaja untuk melakukan aktifitas sosial juga dikuatkan dengan penelitian yang dilakukan oleh Vallentina (2007), tentang rendahnya 
perilaku prososial pada remaja dapat dilihat dari rendahnya perilaku tolong-menolong pada remaja. Hal ini juga terjadi di lingkungan SMA di daerah Salatiga, misalnya saat ada seorang teman yang akan meminjam catatan tetapi teman tersebut bukan merupakan teman dekat mereka, maka mereka tidak mau meminjamkan catatan tersebut dengan alasan catatan tersebut akan dipakai untuk belajar. Demikian pula bila ada teman yang minta tolong diajari mata pelajaran tertentu yang tidak mereka mengerti, maka seringkali siswa yang dimintai tolong tersebut menolak untuk membantu dengan berbagai alasan. Hal tersebut bila tidak diatasi bisa menyebabkan semakin rendahnya sikap ketidakpedulian mereka terhadap orang lain yang nantinya dapat mengakibatkan mereka tumbuh menjadi orang - orang yang memiliki sifat individual tinggi dan tidak suka menolong tanpa pamrih.

Perilaku prososial itu sebenarnya adalah salah satu perilaku yang dilakukan oleh seseorang guna menolong orang lain tanpa mengharap imbalan apapun. Baron \& Byrne 2012 dalam fikriyah (2019), mengungkapkan bahwa tingkah laku prososial adalah segala tindakan apapun yang menguntungkan orang lain. Sears, Freedman, \& Peplau dalam dalam fikriyah (2019), menjelaskan perilaku prososial meliputi segala bentuk tindakan yang dilakukan atau direncanakan untuk menolong orang lain, tanpa memperdulikan motif motif si penolong. Berdasarkan definisi perilaku prososial yang telah diuraikan oleh beberapa ahli di atas maka dapat disimpulkan bahwa perilaku prososial merupakan segala bentuk perilaku yang dilakukan atau direncanakan oleh seseorang untuk menolong orang lain baik dalam bentuk materi, fisik maupun psikologis tanpa mengharapkan imbalan.

Kemampuan prososial yang muncul pada diri remaja dipengaruhi oleh pengaruh diri dan kecerdasan emosi dari hasil penelitian tersebut bahwa ada pengaruh konsep diri dan kecerdasan emosi terhadap perilaku prososial pada remaja (Masela 2019). Selain itu perilaku-perilaku prososial yang dikemukakan oleh remaja juga dipengaruhi oleh empati, jika remaja yang ada didalam organisasi keagamaan itu memiliki empati yang rendah maka remaja tidak memiliki perilaku prososial untuk saling membantu antara anggota organisasi yang terlibat dalam kegiatan rutin tersebut (Anjani 2018).

Remaja di era digital saat ini cenderung memiliki kepedulian sosial yang cenderung rendah hal ini dibuktikan dengan penelitian yang dilakukan oleh Harefa \& Indrawati (2014), menunjukkan terdapat perbedaan perilaku prososial antara siswa yang berasal dari Madrasah Aliyah Asy Syarifah Mranggen Demak dan siswa yang berasal dari SMA Ronggolawe Semarang. Hipotesis mengatakan bahwa terdapat perbedaan 
perilaku prososial antara siswa yang berasal dari Madrasah Aliyah Asy Syarifah Mranggen Demak dan siswa yang berasal dari SMA Ronggolawe Semarang terbukti. Perilaku prososial siswa Madrasah Aliyah Asy Syarifah lebih tinggi dibandingkan dengan rata-rata perilaku prososial pada SMA Ronggolawe Semarang. Jadi penelitian ini membuktikan bahwa sekolah di lingkungan pondok pesantren mempunyai perilaku prososial lebih baik dibandingkan dengan sekolah umum. Jadi hasil penelitian ini membuktikan bahwa pengetahuan agama berhasil membentuk kepribadian siswa terutama perilaku prososialnya.

Remaja yang tergabung dalam organisasi keagamaan seharusnya memiliki dorongan untuk bekerja sama karena didalam organisasi keagamaan ini remaja diajarkan untuk peduli dengan lingkungan, menganal kepedulian antar sesama individu, mengenal tuhan, diajarkan untuk saling membantu, namun kecenderung remaja yang gabung dalam organisasi keagamaan ini memiliki sikap cenderung lebih pasif dalam aktivitasaktivitas keagamaan, jarang ada yang peduli dengan kegiatan-kegiatan yang dilakukan.

Mengetahui perilaku prososial pada remaja yang aktif dalam organisasi keagamaan menggunakan apakah sebenarnya remaja yang tergabung dalam organisasi itu tidak mengetahui ajaran agama yang telah diberikan, sehingga remaja cenderung rendah untuk memahami ajaran agama dan tidak memiliki kepedulian antar individu yang tinggi ataupun perilaku tolong menolong.

Selain itu perilaku empati juga berpengaruh penting terhadap perilaku prososial. Akan tetapi remaja yang aktif dalam organisasi keagamaan cenderung lebih tidak peduli dengan penderitaan orang lain, seperti halnya masyarakat mengalami kebakaran pada rumahnya, remaja tidak memikirkan hal itu dan memikirkan kalau sudah ada orang dewasa yang menolongnya, dari hal ini remaja kurang ikut merasakan perasaan orang lain yang mengalami musibah.

Menurut Hoffman dalam Gunawan (2019), empati adalah respon berupa afeksi atau perasaan yang dimunculkan oleh seseorang kepada orang lain dan respon tersebut lebih disesuaikan pada situasi orang lain daripada situasi diri sendiri. Adapun menurut Kohut, empati adalah kemampuan untuk berfikir dan merasa dirinya masuk ke dalam kehidupan batin orang lain. Lebih lanjut menurut Hojat empati adalah atribut kognitif yang kadang-kadang menampilkan pemahaman dari orang lain, dan sebagai keadaan pikiran emosional yang menampilkan berbagai perasaan sebagai sebuah konsep yang melibatkan kognisi dan emosi. Dari pendapat para teoritikus dapat disimpulkan, bahwa yang dimaksud dengan empati adalah menunjukkan pemahaman seseorang agar dapat 
merasakan dan mengalami pengalaman emosional yang dirasakan orang lain dengan memunculkan suatu tindakan positif dalam rangka untuk membantu orang tersebut.

Hasil penelitian yang dilakukan oleh Kavita Yusthya Anjan (2018), variabel empati dan variabel perilaku prososial mempunyai hubungan yang positif dan searah sehingga hipotesis yang menyatakan bahwa empati mempunyai hubungan dengan perilaku prososial dapat diterima, sedangkan hipotesis yang menyatakan empati tidak berhubungan dengan perilaku prososial ditolak.

\section{Metode}

Prosedur mendapatkan partisipan dalam penelitian ini dilakukan oleh peneliti beberapa tahapan berikut : (a) peneliti mencari partisipan dengan cara menyampaikan secara langsung kepada subyek yang dianggap sesuai dengan karakteristik yang telah ditetapkan oleh peneliti ataupun dengan cara membagikan informasi melalui group whatsapp, (b) peneliti membagikan skala sebagai alat ukur penelitian dalam bentuk google form, (c) Remaja yang aktif dalam organisasi keagamaan di desa Segunung Mojokerto yang berkenan menjadi partisipan akan mengisi skala yang telah dibagikan oleh peneliti, dan (d) peneliti mencatat seluruh data penelitian yang telah diperoleh dari partisipan. ubyek penelitian dalam penelitian ini adalah remaja putra dan putri yang aktif dalam organisasi keagamaan di desa Segunung Mojokerto, yang jumlah populasi 150 remaja. Penelitian ini akan menggunakan partisipan yang berjumlah 109 orang. Penentuan jumlah partisipan tersebut dihitung dengan menggunakan rumus Slovin. Penelitian ini menggunakan desain penelitian jenis kuantitatif, metode yang digunakan adalah metode yang sesuai dengan objek penelitian dan tujuan penelitian yang akan dicapai secara sistematik. Metode pengumpulan data yang digunakan dalam penelitian ini adalah metode skala atau pernyataan. Subyek penelitian akan dipilih menggunakan metode insidental sampling. Penelitian ini menggunakan teknik statistic non parametric yaitu uji Kendall's dengan menguji variabel keikutsertaan pada organisaswi keagamaan dan empati dengan perilaku prososial dengan menggunakan SPSS 20.0 for Windows.

\section{Hasil}

Hasil deskriptif presentase skala perilaku prososial, keikutsertaan pada organisasi keagamaan dan empati dijabarkan tabel 1, 2, dan 3. Berdasarkan hasil perhitungan perilaku prososial yang telah dilakukan diperoleh sebanyak 6 partisipan atau sekitar 5,504\% mendapatkan skor SR (Sangat Rendah) dengan rentang nilai berada $\leq 63$. Sementara itu terdapat 24 partisipan atau sekitar 22,018\% yang memperoleh skor R 
(Rendah) dengan rentang nilai 76 - 64. Selanjutnya sebanyak 43 partisipan atau sekitar 39,449\% berhasil mendapatkan skor S (Sedang) dengan rentang nilai 88 - 77. Kemudian terdapat 36 partisipan atau sekitar 33,027\% yang berhasil mendapatkan skor T (Tinggi) dengan rentang nilai berada pada 101 - 89. Adapun hanya terdapat 0 partisipan atau sekitar 0\% yang mendapatkan skor ST (Sangat Tinggi) dengan rentang nilai $\geq 102$. Berdasarkan hasil yang diperoleh maka dapat dikatakan bahwa perilaku prososial yang dilakukan oleh partisipan penelitian, sebagian besar dalam kategori sedang.

Berdasarkan hasil perhitungan keikutsertaan pada organisasi keagamaan yang telah dilakukan, diperoleh sebanyak 9 partisipan atau sekitar 8,256\% mendapat skor SR (Sangat Rendah) dengan rentang nilai berada pada $\leq 70$. Sementara itu terdapat 17 partisipan atau sekitar 15,596\% yang memperoleh skor R (Rendah) dengan rentang nilai 84 - 71. Selanjutnya, sebanyak 46 partisipan atau sekitar 42,201\% berhasil mendapatkan skor S (Sedang) dengan rentang nilai 98 - 85. Kemudian terdapat 37 partisipan atau sekitar 33,944\% yang berhasil mendapatkan skor T (Tinggi) dengan rentang nilai berada pada 112 - 99. Adapun hanya terdapat 0 partisipan atau sekitar 0\% yang mendapatkan skor ST (Sangat Tinggi) dengan rentang nilai $\geq 113$. maka dapat dikatakan bahwa keikutsertaan pada organisasi keagamaan yang dilakukan oleh partisipan penelitian sebagian besar dalam kategori yang sedang, yang berarti subjek yang tergabung dalam organisasi keagamaan cenderung tidak konsisten untuk mengikuti kegiatan ataupun hal yang sedang dilakukan dalam organisasi keagamaan.

Berdasarkan hasil penghitungan empati yang telah dilakukan, terdapat sebanyak 3 partisipan atau sekitar 2,752\% mendapatkan skor KS (Kurang Sekali) dengan rentang nilai berada pada $\leq 58$. Sementara itu terdapat 28 partisipan atau sekitar $25,688 \%$ yang memperoleh skor K (Kurang) dengan rentang nilai 70-59. Selanjutnya, sebanyak 43 partisipan atau sekitar 39,449\% berhasil mendapatkan skor S (Sedang) dengan rentang nilai 81-71. Kemudian terdapat 35 partisipan atau sekitar 32,110\% yang berhasil mendapatkan skor B (Baik) dengan rentang nilai berada pada 92-82. Adapun hanya terdapat 0 partisipan atau sekitar 0\% yang mendapatkan skor BS (Baik Sekali) dengan rentang nilai $\geq 93$. Maka dapat dikatakan bahwa empati yang dilakukan oleh partisipan penelitian, sebagian besar dalam kategori yang sedang. 
Philanthropy Journal of Psychology

Vol 5 Nomor 1 (2021), 206-217

ISSN 2580-6076 (Print), ISSN 2580-8532 (Online)

Tabel 1. Hasil Interpretasi Skor Skala Perilaku Prososial

\begin{tabular}{ccccc}
\hline Variabel & $\begin{array}{c}\text { Rentang } \\
\text { Nilai }\end{array}$ & Kategori & $\mathbf{N}$ & Persentase \\
\hline & $\leq 63$ & SR & 6 & $5,504 \%$ \\
\cline { 2 - 5 } & $64-76$ & $\mathrm{R}$ & 24 & $22,018 \%$ \\
\cline { 2 - 5 } Perilaku & $77-88$ & $\mathrm{~S}$ & 43 & $39,449 \%$ \\
& & $\mathrm{~T}$ & 36 & $33,027 \%$ \\
\cline { 2 - 5 } & $89-101$ & $\mathrm{ST}$ & 0 & $0 \%$ \\
\hline Trososial & $\geq 102$ & & $\mathbf{1 0 9}$ & $\mathbf{9 9 , 9 9 8 \%}$
\end{tabular}

Sumber : Output Statistik Program SPSS 20 IBM for windows

Tabel 2. Hasil Interpretasi Skor Skala Keikutsertaan pada Organisasi Keagamaan

\begin{tabular}{|c|c|c|c|c|}
\hline Variabel & $\begin{array}{c}\text { Rentan } \\
\text { g Nilai }\end{array}$ & $\begin{array}{c}\text { Kategor } \\
\text { i }\end{array}$ & $\mathbf{N}$ & $\begin{array}{c}\text { Persentas } \\
\text { e }\end{array}$ \\
\hline \multirow{5}{*}{$\begin{array}{c}\text { Keikutsertaa } \\
\text { n pada } \\
\text { Organisasi } \\
\text { Keagamaan }\end{array}$} & $\leq 70$ & SR & 9 & $8,256 \%$ \\
\hline & $84-71$ & $\mathrm{R}$ & 17 & $15,596 \%$ \\
\hline & $98-85$ & $S$ & 46 & $42,201 \%$ \\
\hline & $\begin{array}{c}112- \\
99\end{array}$ & $\mathrm{~T}$ & 37 & $33,944 \%$ \\
\hline & $\geq 113$ & ST & 0 & $0 \%$ \\
\hline Total & & & $\begin{array}{r}10 \\
9\end{array}$ & 99,997\% \\
\hline
\end{tabular}

Sumber : Output Statistik Program SPSS 20 IBM for window

Tabel 3. Hasil Interpretasi Skor Skala Empati

\begin{tabular}{|c|c|c|c|c|}
\hline Variabel & $\begin{array}{c}\text { Rentang } \\
\text { Nilai }\end{array}$ & Kategori & $\mathbf{N}$ & Persentase \\
\hline \multirow{5}{*}{ Empati } & $\leq 58$ & $\mathrm{KS}$ & 3 & $2,752 \%$ \\
\hline & $70-59$ & $\mathrm{~K}$ & 28 & $25,688 \%$ \\
\hline & $81-71$ & $S$ & 43 & $39,449 \%$ \\
\hline & $92-82$ & B & 35 & $32,110 \%$ \\
\hline & $\geq 93$ & BS & 0 & $0 \%$ \\
\hline Total & & & 109 & $99,999 \%$ \\
\hline
\end{tabular}

Sumber : Output Statistik Program SPSS 20 IBM for windows

Hasil uji normalitas, linearitas, multikolinearitas, heteroskedastisitas dijabarkan tabel 4, 5, 6, dan 7. Berdasarkan hasil pengujian yang telah dilakukan, hasil uji normalitas sebaran untuk variabel perilaku prososial menggunakan Kolmogorov-Smirnov diperoleh nilai signifikansi $p=0,0200<0,05$. Artinya sebaran data berdistribusi NORMAL. Adapun hasil pengujian yang telah dilakukan, hasil uji linieritas hubungan antara variabel keikutsertaan pada organisasi keagamaan dengan empatidiperoleh signifikansi sebesar 
Philanthropy Journal of Psychology

Vol 5 Nomor 1 (2021), 206-217

ISSN 2580-6076 (Print), ISSN 2580-8532 (Online)

$0.001(p>0.05)$. artinya tidak ada hubungan yang linier antara keikut sertaan pada organisasi keagamaan dengan perilaku prososial.Adapun hasil uji linieritas hubungan antara empati dengan perilaku prososial di peroleh signifikansi sebesar $0.684(\mathrm{p}<0.05)$. Artinya ada hubungan yang linier antara variabel empati dengan perilaku prososial. Berdasarkan hasil uji multikolinearitas antara variabel X1 (Keikut Sertaan pada Organisasi Keagamaan) dan X2 (Empati) diperoleh nilai tolerance $=0.351>0.10$ dan nilai VIF $=2.851<10.00$. Artinya tidak ada multikolinieritas / interkorelasi antara variabel X1 (Keikut Sertaan Pada Organisasi Keagamaan) dan X2 (Empati). Berdasarkan hasil uji heteroskedastisitas terhadap variabel keikutsertaan pada organisasi keagamaan dan empati korelasi Spearman's Rho diperoleh signifikansi $=0.167$ (p>0.05) pada variabel keikutsertaan pada organisasi keagamaan dan diperoleh signifikansi $=\mathbf{0 . 1 8 3}$ (p>0.05) pada variabel empati. Artinya tidak terjadi heteroskedastisitas pada kedua variabel.

Tabel 4. Hasil Uji Normalitas

\begin{tabular}{lcccc}
\hline & & \multicolumn{2}{c}{ Kolmogorov-Smirnov } \\
\cline { 2 - 5 } Variabel & Statistic & df & Sig. & Keterangan \\
\hline $\begin{array}{l}\text { Perilaku } \\
\text { Prososial }\end{array}$ & 0.072 & 109 & 0.200 & Normal \\
\hline Sumber: Output Statistik Program SPSS 20 lBM & & & \\
\hline
\end{tabular}

Sumber : Output Statistik Program SPSS 20 IBM for windows

Tabel 5. Hasil Uji Linieritas

\begin{tabular}{lccc}
\hline Variabel & 口 & Sig. & Keterangan \\
\hline $\begin{array}{l}\text { Keikut Sertaan pada } \\
\begin{array}{l}\text { Organisasi Keagamaan - } \\
\text { Perilaku Prososial }\end{array}\end{array}$ & 2.459 & 0.001 & Tidak Linier \\
\hline Empati - Perilaku Prososial & $\begin{array}{c}0 . \\
858\end{array}$ & 0.684 & Linier \\
\hline
\end{tabular}

Sumber : Output Statistik Program SPSS 20 IBM for windows

Tabel 6. Hasil Uji Multikolinieritas

\begin{tabular}{lccc}
\hline \multicolumn{1}{c}{ Variabel } & \multicolumn{2}{c}{ Collinearity Statistics } \\
\cline { 2 - 4 } & Tolerance & VIF & Keterangan \\
\hline $\begin{array}{l}\text { Keikut Sertaan Pada } \\
\text { Organisasi Keagamaan - } \\
\text { Empati }\end{array}$ & 0.351 & 2.851 & $\begin{array}{c}\text { Tidak Terjadi } \\
\text { Multikolinieritas }\end{array}$ \\
\hline
\end{tabular}

Sumber : Output Statistik Program SPSS 20 IBM for windows 
Philanthropy Journal of Psychology

Vol 5 Nomor 1 (2021), 206-217

ISSN 2580-6076 (Print), ISSN 2580-8532 (Online)

Tabel 7. Hasil Uji Heteroskedastisitas

\begin{tabular}{lccc}
\hline \multicolumn{1}{c}{ Variabel } & $\begin{array}{c}\boldsymbol{p} \text { - } \\
\text { value }\end{array}$ & Keterangan & Kesimpulan \\
\hline $\begin{array}{l}\text { Keikutsertaan Pada } \\
\text { Organisasi Keagamaan(X1) }\end{array}$ & 0.167 & $>0.05$ & $\begin{array}{c}\text { Tidak Terjadi } \\
\text { Empati (X2) }\end{array}$ \\
& 0.183 & $>0.05$ & $\begin{array}{c}\text { Heteroskedastisitas } \\
\text { Tidak Terjadi } \\
\text { Heteroskedastisitas }\end{array}$ \\
\hline
\end{tabular}

Sumber : Output Statistik Program SPSS 20 IBM for windows

Tabel 8. Uji Korelasi Kendall's Tau

\begin{tabular}{lcccc}
\hline Kendall's Tau & $\begin{array}{c}\text { Koefisien } \\
\text { Korelasi }\end{array}$ & $\begin{array}{c}\text { Sig } \\
\text { (p) }\end{array}$ & Keterangan & Hipotesis \\
\hline $\begin{array}{l}\text { Keikut sertaan } \\
\text { pada organisasi } \\
\text { keagamaan Perilaku } \\
\text { prososial }\end{array}$ & 0,644 & 0,000 & $<0,05$ & Ditrima \\
\hline $\begin{array}{l}\text { Empati Perilaku prososial } \\
\text { Emp }\end{array}$ & 0,475 & 0,000 & $<0,05$ & Diterima
\end{tabular}

Sumber : Output Statistik Program SPSS 20 IBM for windows

Hasil uji korelasi dengan menggunakan korelasi Kendall's Tau terhadap variabel keikutsertaan pada organisasi keagamaan dan perilaku sosial mendapatkan hasil koefisisen korelasi sebesar $0,644=41 \%$ dan signifikansi $0,000(p<0,05)$ yang artinya terdapat hubungan antara keikutsertaan pada organisasi keagamaan dengan perilaku prososial. Kemudian ditemukan hasil uji korelasi terhadap variabel empati dan perilaku prososial mendapatkan hasil koefisien korelasi sebesar $0,475=22,5 \%$ dan signifikansi $0,000(p<0,05)$ yang artinya adanya hubungan antara variabel empati dengan perilaku prososial.

Kemudian dilakukan pengujian kembali dengan menggunakan uji korelasi kendall's $W$ Test untuk mengetahui hubungan antara kedua variabel independen yaitu keikutsertaan pada organisasi keagamaan, empati dan perilaku prososial.

Tabel 9. Uji Korelasi Kendall's W Test

\begin{tabular}{lcccc}
\hline & $\begin{array}{l}\text { Kendall's } W_{\text {Asymp Sig }} \\
\text { Test } \\
\text { koefisien }\end{array}$ & Keterangan & Hipotesis \\
\hline $\begin{array}{l}\text { Keikutsertaan pada } \\
\begin{array}{l}\text { Organisasi } \\
\text { Keagamaan - Empati }\end{array}\end{array}$ & 0,381 & 0,000 & $<0,05$ & Diterima \\
$\begin{array}{l}\text { Perilaku Prososial } \\
\text { Sumber : Output Statistik Program SPSS 20 IBM for windows }\end{array}$ &
\end{tabular}


Berdasarkan hasil uji korelasi yang dilakukan pada varabel keikutsertaan pada organisasi keagamaan dan empati terhadap perilaku sosial pada tabel diatas menunjukan Asymp signifikansi sebesar $0,000(\mathrm{p}<0,05)$ yang artinya terdapat hubungan yang signifikan antara keikutsertaan pada organisasi keagamaan dan empati terhadap perilaku prososial. Kemudian hasil koefisien determinasi menunjukan angka sebesar 0,38 variabel keikutsertaan pada organisasi keagamaan dan empati hanya memberikan sumbangsi sebesar $14,5 \%$ terhadap perilaku prososial dalam perilaku remaja yang aktif dalam organisasi keagamaan.

\section{Pembahasan}

Berdasarkan hasil uji kendall'S W Test melalui program Statistical Package for the Social Sciences (SPSS) versi 20.0 for windows, yang mengatakan bahwa terdapat hubungan yang signifikan antara keikutsertaan pada organisasi keagamaan dan perilaku prososial. Melalui hasil tersebut, maka hipotesis yang diajukan dalam penelitian ini terbukti atau dapat diterima, yang berarti keikutsertaan pada organisasi keagamaan sangat berpengaruh terhadap perilaku prososial remaja yang aktif dalam organisasi keagamaan, remaja yang mengikuti organisasi keagamaan itu hal yang sangat penting, karena organisasi keagamaan sangat berpengaruh oleh keyakinan (behavioral beliefs) sebagai akibat dari tingkah laku prososial yang dilakukan, Keyakinan individu meliputi beliefs strength dan outcome evaluation. Pandangan atas perilaku yang tergabung dalam organisasi keagamaan diyakini mempunyai dampak langsung terhadap kehendak untuk terbentuknya perilaku prososial yang kemudian diaplikasikan dengan kontrol perilaku persepsian dan norma subjektif (Ajzen, 1991). penelitian ini selaras dengan penelitian yang sudah dilakukan oleh Muzakkir (2013), Ilyas Sudikno Yahya \& Zaenal Abidin (2018), Nurhafiza (2019), Juliwati \& Suharnan (2014).

Adapun hasil penelitian berikutnya dapat diketahui bahwa terdapat hubungan positif yang signifikan antara variabel empati dengan perilaku prososial. Hasil tersebut menunjukkan bahwa semakin tinggi empati yang dimiliki oleh remaja, maka semakin tinggi perilaku prososial yang dilakukan oleh remaja. Sebaliknya, apabila semakin rendah empati maka semakin rendah pula perilaku prososial yang dilakukan oleh remaja. Hasil ini dapat diartikan bahwa empati dapat mempengaruhi perilaku prososial pada remaja yang aktif dalam organisasi keagamaan.

Hasil tersebut senada dengan pernyataan Schlenker dan Britt (Baron \& Byrne, 2005), individu yang memiliki empati tinggi lebih termotivasi menolong seseorang daripada mereka yang memiliki empati rendah. Melalui hasil tersebut, dapat dikatakan 
bahwa hipotesis kedua dalam penelitian ini dapat diterima. Hasil penelitian ini mengatakan bahwa lebih tinggi nilai signifikan keikutsertaan pada organisasi keagamaan dibandingkan dengan empati yang mempengaruhi perilaku prososial, akan tetapi bukan berarti empati tidak penting untuk proses pembentuknya perilaku prososial, tetapi hasil menjelaskan bahwa remaja dapat membentuk perilaku empati jika remaja terlibat dalam organisasi keagamaan, dalam hal ini remaja dapat mengaplikasikan perilaku empati dikehidupan masyarakat melalui adanya keikutsertaan pada organisasi keagamaan. Adapun hasil dari penelitian ini selaras dengan penelitian yang dilakukan oleh, Kavita Yusthya Anjani dengan judul, Rr. Sukma Dian Puspita \& Gumgum Gumelar, Noor Ika Widaningsih \& Dra. Indriyati Eko P, S.Psi., M.Si.

Adapun hasil hipotesis yang ketiga yang diuji secara bersamaan dilakukan pada varabel keikutsertaan pada organisasi keagamaan dan empati terhadap perilaku sosial pada memberikan sumbangsi sebesar $14,5 \%$ terhadap perilaku prososial dalam perilaku remaja yang aktif dalam organisasi keagamaan, dan adanya hubungan antara keikutsertaan pada organisasi keagamaan dan empati dengan perilaku prososial saling berkaitan sehingga remaja yang ikutserta dalam organisasi keagamaan dapat memicu timbulnya empati, kemudian secara otomatis dapat membentuk perilaku prososial.

Berdasarkan hasil penelitian, maka dapat dibuktikan bahwa dengan keikutsertaan pada organisasi keagamaan yang tinggi dapat meningkatkan perilaku prososial pada remaja yang aktif dalam organisasi keagamaan. Hal ini dikarenakan remaja yang aktif dalam organisasi keagamaan memiliki sikap tolong menolong, dermawan, jujur, dan tanggung jawab seperti yang telah diajarkan di dalam agama melalui organisasi keagamaan. Selain itu dalam penelitian ini juga membuktikan bahwa tingginya empati dapat berpengaruh besar terhadap perilaku prososial pada remaja yang aktif dalam organisasi keagamaan. Hal ini dikarenakan remaja yang aktif dalam organisasi keagamaan mampu merasakan perasaan orang lain, membuat remaja lebih suka menolong dengan adanya perasaan belas kasih dan merasakan penderitaan orang lain.

\section{Kesimpulan}

Berdasarkan hasil dari penelitian yang telah dilakukan kepada remaja yang aktif dalam organisasi keagamaan di desa Segunung Mojokerto dapat disimpulkan bahwa terdapat hubungan positif antara keikutsertaan pada organisasi keagaaman dan perilaku prososial, hal ini mengatakan bahwa keikutsertaan pada organisasi keagamaan dan empati saling berhubungan, serta terdapat hubunganan positif antara empati dengan 
perilaku prososial, yang berarti adanya keterkaitan antara variabel empati dengan perilaku prososial, dan terdapat hubungan posistif antara keikutsertaan pada organisasikeagamaan dan empati dengan perilaku prososial, yang dapat diartikan bahwa keikutsertaan pada organisasi keagamaan dan empati dengan perilaku prososial ada pengaruh penting yang mengatakan ketiga variabel tersebut saling berkaitan.

\section{Referensi}

Fikriyah Novitasari, A. N. A. (2019). Hubungan Antara Pendidikan Kepramukaan Dengan Perilaku Prososial Peserta Didik Smp Negeri 1 Taman Sidoarjo. J+ Plus Unesa, $8(2)$.

Gunawan, I. M. S., \& Huda, N. (2019). Menumbuhkan Empati Sebagai Upaya Meningkatkan Nilai-Nilai Moralitas Siswa Melalui Pelayanan Bimbingan Dan Konseling. Realita: Jurnal Bimbingan dan Konseling, 3(5).

Kurniawan, Harefa \& Endag Sri Indrawati. (2014) Perbedaan Perilaku Prososial Siswa Madrasah (MA) Berbasis Pondok Pesantren Dan Sekolah Menengah Umum (SMP). Artikel. Psikologi UNDIP (hal. 41 - 67). Semarang: Psikodimensia.

Lu, T., Li, L., Niu, L., Jin, S., \& French, D. C. (2018). Relations between popularity and prosocial behavior in middle school and high school Chinese adolescents. International Journal of Behavioral Development, 42(2), 175-181.

Masela, M. S. (2019). Pengaruh Antara Konsep Diri Dan Kecerdasan Emosi Terhadap Perilaku Prososial Pada Remaja. Psikovidya, 23(2), 214-224.

Pratitis, N. T. (2013). Perbedaan Agresivitas Dan Prososial Antara Siswa Smp Negeri Di Kota Dengan Di Desa. Wacana, 5(1).

Yusthya Anjani, K., \& Anugerah Izzati, U. M. I. (2018). Hubungan antara Empati dengan Perilaku Prososial pada Siswa SMK Swasta X di Surabaya. Character: Jurnal Penelitian Psikologi., 5(2).

Yusthya Anjani, K., \& Anugerah Izzati, U. M. I. (2018). Hubungan antara Empati dengan Perilaku Prososial pada Siswa SMK Swasta X di Surabaya. Character: Jurnal Penelitian Psikologi., 5(2). 